\title{
Quality of Ground and Surface Water of Rajshahi City Area for Sustainable Drinking Water Source
}

\author{
M. T. Rasul ${ }^{1}$ and M. S. Jahan $^{2}$ \\ ${ }^{1}$ Civil Engineering Department, International University of Business Agriculture and Technology, \\ Uttara, Dhaka-1230, Bangladesh \\ ${ }^{2}$ Institute of Environmental Science (IES), University of Rajshahi, Rajshahi-6205, Bangladesh \\ Received 8 January 2010, accepted in final revised form 9 July 2010
}

\begin{abstract}
An investigation was carried out to assess the water qualities and extents of impurities in groundwater and surface water (Padma river water) in Rajshahi City area. Water samples from a total of 330 tube wells and five spots of the river Padma were analysed for physicochemical, biological and hydrological parameters with standard methods. Among all considered parameters of ground water, concentrations of arsenic, iron, manganese, total hardness, and total coliform and faecal coliform bacteria were found above the permissible limits for potable water. In case of the river Padma, biochemical oxygen demand, chemical oxygen demand, total coliform, faecal coliform and suspended solids exceeded permissible limits. Both ground and river water must be treated properly before distribution for drinking purpose. Finally, the Padma is recommended as the most sustainable drinking water source for Rajshahi City Corporation area.
\end{abstract}

Keywords: Rajshahi City; Ground water; Surface water; Quality control.

(C) 2010 JSR Publications. ISSN: 2070-0237 (Print); 2070-0245 (Online). All rights reserved.

DOI: 10.3329 /jsr.v2i3.4093 J. Sci. Res. 2 (3), 577-584 (2010)

\section{Introduction}

Rajshahi, the fourth largest city of Bangladesh, lies between $24^{0} 21^{\prime}$ and $24^{0} 25^{\prime}$ North latitudes and between $88^{\circ} 32^{\prime}$ and $88^{\circ} 40^{\prime}$ East longitudes, with an area of about 96.68 sq. $\mathrm{km}$. It is surrounded by two major outfall rivers, namely the Padma and the Barnai. The Padma is situated at the southern border and the Barnai is about $6 \mathrm{~km}$ away from the northern edge of the city [1]. According to the census of 2001 the population was $3,88,020$ [2]. Considering an average projected growth rate of $2.3 \%$ the population will be about 0.6 million in 2020 .

\footnotetext{
${ }^{1}$ Corresponding author: tarekhrasul@yahoo.com
} 
The Rajshahi Water Supply Master Plan was implemented by the Department of Public Health Engineering with the support of the Dutch Government in 1981. This groundwater is supplied from 40 deep tube wells through pipe networks of $200 \mathrm{~km}$ reticulated over an area of 93.34 square kilometres. The system is designed to serve the estimated population of 0.4 million in the year 2000 [3]. At present Rajshahi City Corporation (RCC) can supply only about $32,000 \mathrm{~m}^{3} /$ day out of a total demand of 85,000 $\mathrm{m}^{3} /$ day. About $55 \%$ of the population has access to pipe water and the rest take water from hand tube wells in the municipal area. If we consider the growth of the population, the demand of water would be $2,40,000 \mathrm{~m}^{3} /$ day by 2020 [4].

The safe drinking water plays an important role for the development of good health condition of a nation. The World Health Organization (WHO) states that water containing many types of impurities from various sources causes different types of water borne diseases and each year millions of people suffer from such diseases due to unsafe drinking water supplies [5].

The aim of the present study was to assess the quality of drinking water uplifted from hand tube wells, shallow tube wells and deep tube wells in the Rajshahi City Corporation area along with the quality and quantity of the river Padma water as the alternate sustainable option for mitigation of existing water scarcity in the concerned area.

\section{Method}

At first a digital map of RCC was prepared with GIS programmes (Arc view 3.2a and Cartalinx) and the total area was divided into several grids at 30 second intervals. About 5 to 7 tube wells were selected from each grids at the same time the geographical locations of the tube wells were noted with GPS (MAGELLAN GPS 310) for further identification. Initially 330 samples were tested for arsenic by the field kit (MERCK Kit). Finally, the sources, which were found with arsenic contaminations of $0.05 \mathrm{ppm}$ and above, were selected for detail laboratory analysis. Considering an alternative source of water 5 spots in different location of the river Padma were selected in the study area for laboratory analysis also.

Different water quality parameters like arsenic (As), iron (Fe), manganese (Mn), calcium $(\mathrm{Ca})$, magnesium $(\mathrm{Mg})$, zinc $(\mathrm{Zn})$, copper $(\mathrm{Cu})$, sodium $(\mathrm{Na})$, potassium $(\mathrm{K})$, total hardness $(\mathrm{TH})$, alkalinity, $\mathrm{pH}$, electrical conductivity $\left(E_{\mathrm{c}}\right)$, sulphate $\left(\mathrm{SO}_{4}\right)$, nitrate $\left(\mathrm{NO}_{3}\right)$, nitrite $\left(\mathrm{NO}_{2}\right)$, ammonia $\left(\mathrm{NH}_{4}\right)$, phosphate $\left(\mathrm{PO}_{4}\right)$, chloride $(\mathrm{Cl})$, dissolved oxygen $(\mathrm{DO})$, biochemical oxygen demand $\left(\mathrm{BOD}_{5}\right)$, chemical oxygen demand $(\mathrm{COD})$, total coliform bacteria (TC), faecal coliform bacteria (FC) and total suspended solids (TSS) were analysed in the laboratory with Standard Methods [6]. UV Visible Spectrophotometer (Shimadzu, Model UV mini-1240, Japan) was used for colorimetric detections. Atomic Absorption Spectrophotometer (Perkin-Elmer, Model 3110) was used to detect metals. Microbiological Incubator (BINDER, Model BD-53, Germany) was used for bacterial tests. Electrical conductivity $\left(E_{\mathrm{c}}\right)$ and $\mathrm{pH}$ were measured with $E_{\mathrm{c}}$-Meter (HANNA) and 
pH-Meter (HANNA) respectively. Some computer programmes like Microsoft Excel and SPSS were used for statistical analysis of the data.

\section{Results}

The water quality of the two major sources of Rajshahi City Corporation area are compared with Bangladesh Drinking Water Standards (BDWS), World Health Organization Drinking Water Standards (WHODWS) and Treatable Surface Water Standards (TSWS) [7] and presented in the Table 1.

Table 1. The mean values of three years (2003-2006) samples along with BDWS, WHODWS and TSWS.

\begin{tabular}{|c|c|c|c|c|c|}
\hline \multirow[t]{2}{*}{ Parameters } & \multicolumn{2}{|c|}{ Water type } & \multicolumn{3}{|c|}{ Standard values } \\
\hline & $\begin{array}{c}\text { Groundwater } \\
\text { Mean } \pm \text { SD }\end{array}$ & $\begin{array}{l}\text { River water } \\
\text { mean } \pm \text { SD }\end{array}$ & BDWS & WHODWS & TSWS \\
\hline As ppm & $0.046 \pm 0.025$ & $<0.01$ & 0.05 & 0.01 & - \\
\hline Fe ppm & $5.486 \pm 3.518$ & $0.72 \pm 0.15$ & $0.3-1$ & 0.3 & - \\
\hline Mn ppm & $0.368 \pm 0.53$ & $0.07 \pm 0.01$ & 0.1 & 0.01 & - \\
\hline Ca ppm & $90.6 \pm 15.71$ & $24.9 \pm 5.30$ & 75 & - & - \\
\hline $\mathrm{Mg} \mathrm{ppm}$ & $26.27 \pm 4.283$ & $10.2 \pm 1.04$ & $30-35$ & - & - \\
\hline Zn ppm & - & $0.06 \pm 0.01$ & 5 & 3 & - \\
\hline $\mathrm{Cu}$ ppm & - & $0.01 \pm 0.00$ & 1 & 1 & - \\
\hline $\mathrm{Na} p p m$ & - & $18.4 \pm 4.41$ & 200 & 200 & - \\
\hline $\mathrm{K}$ ppm & - & $2.86 \pm 0.44$ & 12 & - & - \\
\hline T. H. ppm & $347.2 \pm 52.29$ & $105 \pm 16.06$ & $200-500$ & - & - \\
\hline Alkalinity ppm & - & $101 \pm 17.48$ & 100 & 100 & - \\
\hline $\mathrm{pH}$ & $7.264 \pm 0.319$ & $7.67 \pm 0.12$ & $6.5-8.5$ & $6.5-8.5$ & $6.5-8.5$ \\
\hline Ec dS/m & - & $0.29 \pm 0.06$ & - & - & - \\
\hline $\mathrm{SO}_{4} \mathrm{ppm}$ & $17.67 \pm 14.12$ & $10 \pm 2.46$ & 400 & 250 & - \\
\hline $\mathrm{NO}_{3} \mathrm{ppm}$ & $4.12 \pm 1.78$ & $6.66 \pm 0.77$ & 10 & 50 & - \\
\hline $\mathrm{NO}_{2} \mathrm{ppm}$ & - & $0.07 \pm 0.02$ & 1 & 3 & - \\
\hline $\mathrm{NH}_{3} \mathrm{ppm}$ & - & $0.034 \pm 0.01$ & 0.5 & 1.5 & - \\
\hline $\mathrm{PO}_{4} \mathrm{ppm}$ & $0.76 \pm 0.096$ & $0.36 \pm 0.05$ & 6 & - & - \\
\hline $\mathrm{Cl} \mathrm{ppm}$ & $36.76 \pm 14.54$ & $14.7 \pm 0.87$ & $150-600$ & 250 & - \\
\hline DO ppm & - & $7.83 \pm 0.56$ & 6 & - & $\geq 6$ \\
\hline $\mathrm{BOD}_{5} \mathrm{ppm}$ & - & $2.21 \pm 0.52$ & 0.2 & - & $\leq 3$ \\
\hline COD ppm & - & $19.5 \pm 2.66$ & 4 & - & - \\
\hline TC ppm & $57 \pm 101$ & $614 \pm 178$ & 0 & 0 & $\leq 5000$ \\
\hline $\mathrm{FC} \mathrm{ppm}$ & $5 \pm 11$ & $184 \pm 91$ & 0 & 0 & - \\
\hline TSS ppm & - & $544 \pm 212$ & 10 & - & - \\
\hline
\end{tabular}

$\mathrm{SD}=$ standard deviation. 
During the study period (August 2003 - September 2006) a total of 330 tube wells from the shallow aquifer $(25-50 \mathrm{~m}$ depth) were tested for physicochemical properties of groundwater within the Rajshahi City Corporation area. Out of these 330 tube wells 72 were found having arsenic levels above the WHO guideline value $(0.01 \mathrm{ppm})$, of which 30 exceeded the Bangladesh drinking water standard $(0.05 \mathrm{ppm})$. It may be noted that during the reconnaissance survey by Kit (MERCK field kit) method 81 tube wells were detected having arsenic levels above 0.05 ppm but during the time of laboratory analysis 9 samples were not available due to withdrawal of the tube wells when detected as arsenic contaminated. The maximum concentration of arsenic was found in the study area as 0.116 ppm at Koyerdara $\left(24^{0} 23^{\prime} 51^{\prime \prime}\right.$ North latitude, $88^{\circ} 35^{\prime} 52^{\prime \prime}$ East longitude), which is more than two times of Bangladesh standard.

It was observed that $75 \%$ of hand tube wells were contaminated with total coliform bacteria, of which $59 \%$ with faecal coliform bacteria. Coliform bacterial contamination in groundwater was found at Kasiadanga, Guripara, Thakurmara, Horogram Bazar, Court area, Lokhnath School, Koyerdara, Monnaf More, Talaimari and Islampur.

In the digital map the geographic locations of the arsenic affected tube wells are marked with different colours according to their categories. The GIS based digital map of arsenic for Rajshahi city is given in Fig. 1.

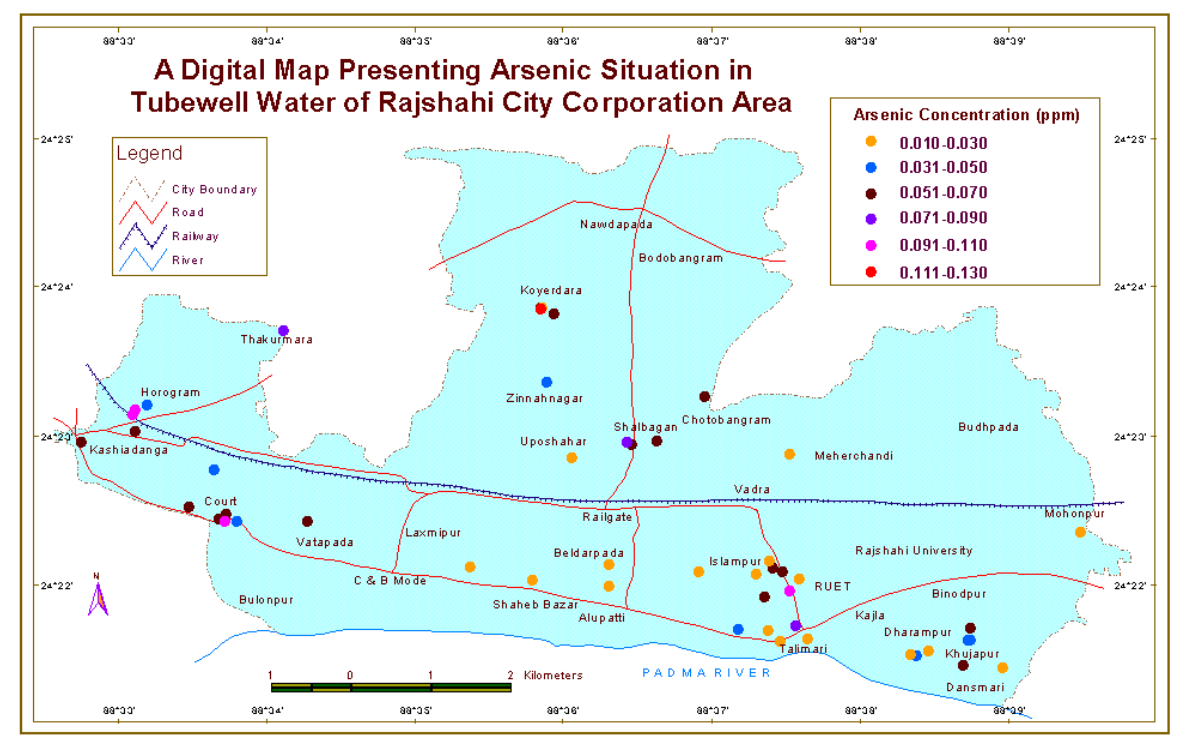

Fig. 1. GIS Based digital map of arsenic situation for Rajshahi city area.

The water level data of the river Padma in the last twelve years reveal that the highest and the lowest water levels remain during August-September and March-April, 
respectively [8]. The average peak level was $17.41 \mathrm{~m}$ in September and the average lowest level was $9.61 \mathrm{~m}$ in April. The discharge data show that the average highest discharge was 38429.72 Cumec in September and the lowest discharge value was 861.76 Cumec in April (Figs. 2a-b).

(a) Average discharge of the river Padma

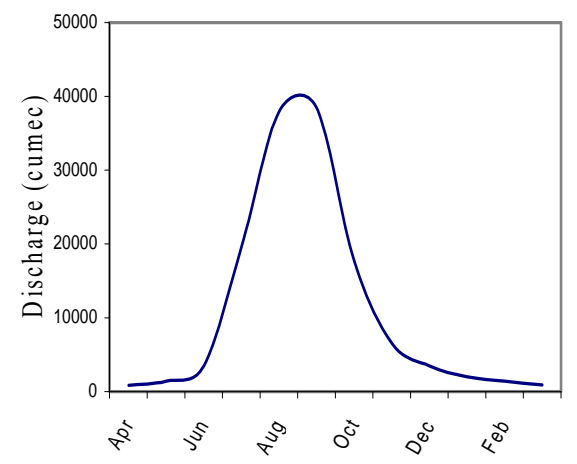

(b) Average water level of the river Padma

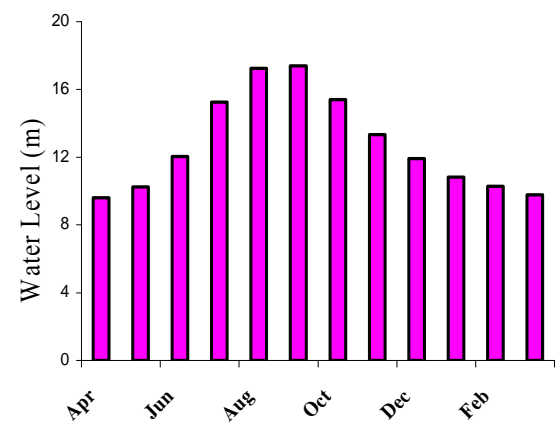

Fig. 2. Monthly variation of discharges and water levels of the Padma.

Analysis of water from five spots in river Padma in three major seasons indicate that the mean concentrations of arsenic, calcium, magnesium, hardness, copper, zinc, sodium, potassium, alkalinity, $\mathrm{pH}$, sulphate, nitrate, nitrite, ammonia, phosphate, chloride and DO were within the Bangladesh and WHO water quality standards (Table 1).

At present the Rajshahi City Corporation expends about Tk.13000.00 per day for extracting water from deep aquifer at the rate of Tk. $0.42 \mathrm{per} \mathrm{m}^{3}$ of water (Tk.3.8/kWH electricity) though it can meet up only about $40 \%$ of the demand. It was estimated that to draw ground water up to the treatment plant about $20 \%$ more power is required than to draw surface water to the same elevation.

\section{Discussion}

The Bangladesh Arsenic Mitigation Water Supply Project analysed 25 deep tube wells water under the management of Rajshahi City Corporation and found that 15 out of those deep tube wells were contaminated with arsenic level above the WHO guide line value $(0.01 \mathrm{ppm})$, of which 4 exceeded the Bangladesh standard $(0.05 \mathrm{ppm})$. They recorded the maximum value as $0.170 \mathrm{ppm}$ at Ramchandrapur pump [9]. The present investigation also reveals that the maximum concentration of arsenic in the ground water is more close to the above finding.

The concentration of iron, manganese and total hardness in tube well water of the study area were very high but the values of $\mathrm{pH}$, sulphate, nitrate, phosphate and chloride 
were found within the permissible limits of both the Bangladesh and WHO standards. However, the permissible limits for iron, manganese and total hardness are $0.3-1 \mathrm{ppm}$, $0.1 \mathrm{ppm}$ and 200-500 ppm, respectively in the Bangladesh standard. Water having hardness above $300 \mathrm{ppm}$ is considered very hard [10]. Although most of the physicochemical parameters of groundwater are not at the alarming stage, the condition of the pathogenic bacteria is exclusively threatening. These facts disclose that the drinking water situation of Rajshahi city is not in a favourable condition for public health.

The study for different options for safe drinking water is urgent for the mitigation of the problem. Considering the geographic and topographic aspects, the water of the Padma was considered an alternative source and the study was carried out accordingly. Rajshahi city is situated on the left bank of the Padma, one of the greatest rivers of Bangladesh. In peak season (August and September) the average maximum discharge of the Padma is about 40,000 Cumec, and the minimum is 1000 Cumec in dry season (March and April) [8]. Though in dry season discharge declines enormously due to the Farakka barrage on the upstream in India, the water level of the river always have an acceptable limit for using the water for commercial purpose and for the recharge of groundwater. From the last 12-year data of the Padma the average discharge in dry season was found about 900 Cumec and the lowest discharge was recorded as 401 Cumec in April, 1995. Therefore, if the Padma river water was considered an alternative source for the water supply system of the city the estimated water demand up to $2020\left(24000 \mathrm{~m}^{3} /\right.$ day $)$ could be met with by extraction of 8.3 Cumec of water in only 8 hours operation period daily.

Some physicochemical, biological and hydrological parameters of the river water were analyzed to verify the acceptability of river water as drinking water source for Rajshahi city area. Though the river water is continuously contaminated with municipal wastes at several points and flowing to the downstream, and the average value of BOD and total coliform bacteria were found above both the WHO and Bangladesh standards, they are within the limit of treatable surface water standard.

To consider the sustainability of the two options, groundwater and river water, we have to consider three major points as availability, extraction and treatment costs and environmental safety. Ground water is available throughout the year but when drought prevails water table depletes and extraction becomes difficult by the conventional method. But the water level and discharge of the Padma remain at a certain extractable level without hampering the aquatic ecology.

The ground water of the study area has high hardness which contains different minerals, like iron, manganese, calcium and magnesium, and in some cases arsenic. But in case of river water the level of these impurities are within the permissible limits. The treatment of these mineral impurities involves comparatively intricate technologies as well as high cost [11]. The river water contains high amounts of suspended solids (sediments) than groundwater, but they could be removed through simple sedimentation techniques. Bacteria and BOD loads of river water could be removed through conventional surface water treatment techniques. In case of disinfection both the groundwater and surface water 
require to be disinfected before distribution. So, in this case no cost difference needs to be calculated.

Over-exploitation of ground water to meet the future increased demand may deplete water table harshly producing acute drinking water problem for the city dwellers. So, deep concern should be paid regarding this issue. Another thing is sludge management. As the ground water may contain arsenic so it will produce arsenic rich toxic sludge. Disposal of this sludge will create another problem which is now a burning question for arsenic removal plants of Bangladesh. On the other hand, the Padma water is safe from arsenic pollution and concentrations of calcium, magnesium, total hardness, phosphate and chlorine of Padma water are much less than those of ground water (Table 1). So management of sludge will be easier.

\section{Conclusion}

The study shows that depletion of aquifer along with contamination of arsenic and coliform bacteria, and high concentrations of iron and manganese, and total hardness are the major constraints for drinking water supply in Rajshahi City Corporation area. Water from any source, either groundwater or surface water, must be treated before use. Comparing the quality of ground water with the Padma water it was found that the river water is more suitable for use as potable water after proper treatment. So, it could be concluded that river Padma water will be the most sustainable option for mitigating the water problem in Rajshahi City.

\section{Acknowledgements}

The authors are highly grateful to the authority of the Institute of Environmental Science, University of Rajshahi, for giving all types of facilities to conduct the research work and for preparation of the manuscript.They are also highly indebted to Professor Dr. A.R.Khan Department of Zoology, Rajshahi University, for his painstaking endeavour to go through the manuscript.

\section{Reference}

1. AQUA, Feasibility Study and Preparation of Drainage Master Plan for Rajshahi City Corporation (Final Report, Aqua Consultant \& Associates Ltd., 40, Nayapaltan, Dhaka, Bangladesh, 1994).

2. BBS, Bangladesh Population Census 2001, National Report (Bangladesh Bureau of Statistics, Planning Division, Ministry of Planning, Government of the Peoples Republic of Bangladesh, Dhaka, 2003).

3. G. B. Sarkar, and H. Heijnen, Rajshahi Healthy Ward Pilot Water Supply Surveillance, WHO/DPHE, Dhaka, Bangladesh (Retrieved on 20 December 2005 from: http://www.lboro.ac.uk/watermark/reports/rajshahi-healthy-ward-water-supply-surveillance.pdf, 2000).

4. DDC, Structure Plan, Master Plan and Detailed Area Development Plan for Rajshahi Metropolitan City (Development Design Consultants Limited, Dhaka, 2002). 


\section{Quality of Ground and Surface Water}

5. M. F. Ahmed and M. M. Rahman, Water Supply \& Sanitation, Rural and Low Income Urban Communities. (ITN-Bangladesh, Center for Water Supply and Waste Management, BUET, Dhaka, Bangladesh, 2000).

6. APHA, AWWA, WEF, Standard Methods for the Examination of Water and Wastewater, $19^{\text {th }}$ Edition (1015 Fifteenth Street NW, Washington, DC 2005, 1995).

7. Bangladesh Gazette, Notification (Ministry of Environment and forest, Government of the Peoples Republic of Bangladesh, 1997) p. 3124.

8. BWDB, Water Level and Discharge Data of the River Padma (Bangladesh Water Development Board, Rajshahi, Bangladesh, 2004).

9. BAMWSP, Bangladesh Arsenic Mitigation Water Supply Project Report (Retrieved November 11, 2005 from http://www.bamwsp.org, 2002).

10. C. N. Sawyer, P. L. McCarty, and G. F. Parkin, Chemistry for Environmental Engineering, $4^{\text {th }}$ Edition (McGraw-Hill, Inc. New York 1994).

11. S. K. Garg, Water Supply Engineering, Vol-1 (Khan Publishers, 2-B, Nath Market, Nai Sarak, Delhi-110006, 2007). 